\title{
The Effect of the Web Based Digital Story Applications on the Digital Literacy Levels of Turkish Teacher Candidates
}

\author{
Halil Erdem ÇOCUK ${ }^{1} æ(\mathbb{D}$ \\ Tugba YANPAR YELKEN ${ }^{2}$ \\ ${ }^{1,2}$ Mersin University Turkey \\ Email:halilerdemcocuk@gmail.com Tel:05050950033 \\ Email:tvanpar@omail.com Tel:05353061926
}

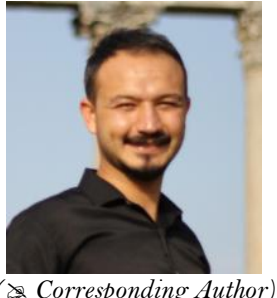

\begin{abstract}
The technological developments that have directed 21 st century skills have brought new content and dimension to narrative by integrating story narration, one of the earliest verbal narrative skills of mankind, with digital technology. The purpose of this study is to determine the effect of web-based digital story preparation on the literacy self-efficacy perceptions of Turkish teacher candidates in the digital media using pre-test, posttest, experimental-control group and semiexperimental design. A total of 60 teacher candidates, including 30 experimental groups and 30 control groups attending to the Teaching Principles and Methods Course in Mersin University Education Faculty Turkish Education Department participated in the study in 2016-2017 academic year. The research data were collected by the "Digital Media-Oriented Literacy Selfefficacy Scale" developed by the researchers. As a result of the study, Digital Media-Oriented Literacy Self-efficacy levels were observed to increased in both groups. However, a statistically significant difference was found only between pre-test and post-test scores of the self-efficacy perceptions of the Turkish teacher candidates who prepared a web-based digital story in the cooperative learning approach. It is suggested regarding the results of the study that in other studies, digital storytelling approach can be utilized by taking into consideration the content of both field and cultural courses, and also that researchers can investigate the effects of digital storytelling in terms of various variables.
\end{abstract}

Keywords: Turkish education, Digital literacy, Digital story, Cooperative learning, Digital material preparation.

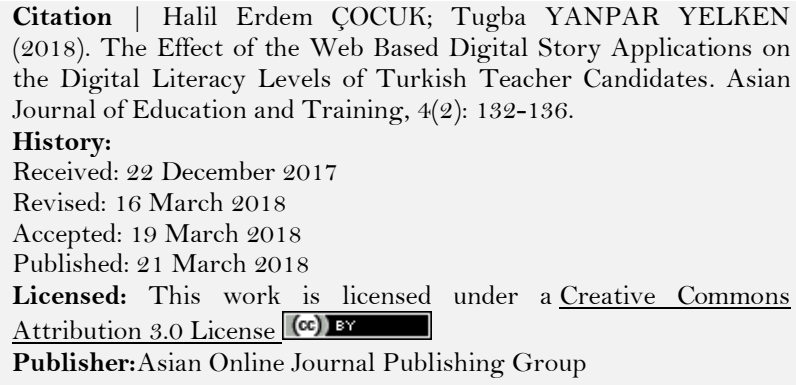

Citation | Halil Erdem COCUK; Tugba YANPAR YELKEN (2018). The Effect of the Web Based Digital Story Applications on the Digital Literacy Levels of Turkish Teacher Candidates. Asian Journal of Education and Training, 4(2): 132-136. History:

Received: 22 December 2017

Revised: 16 March 2018

Accepted: 19 March 2018

Published: 21 March 2018

Licensed: This work is licensed under a Creative Commons Attribution 3.0 License (cc)

Publisher:Asian Online Journal Publishing Group

Contribution/Acknowledgement: Both authors contributed to the conception and design of the study.

Funding: This article is supported by Mersin University with the project code 2016-2-TP3-1927.

Competing Interests: The authors declare that they have no conflict of interests.

Transparency: The authors confirm that the manuscript is an honest, accurate, and transparent account of the study was reported; that no vital features of the study have been omitted; and that any discrepancies from the study as planned have been explained.

study as planned have been explained.
Ethical: This study follows all ethical practices during writing.

\section{Contents}

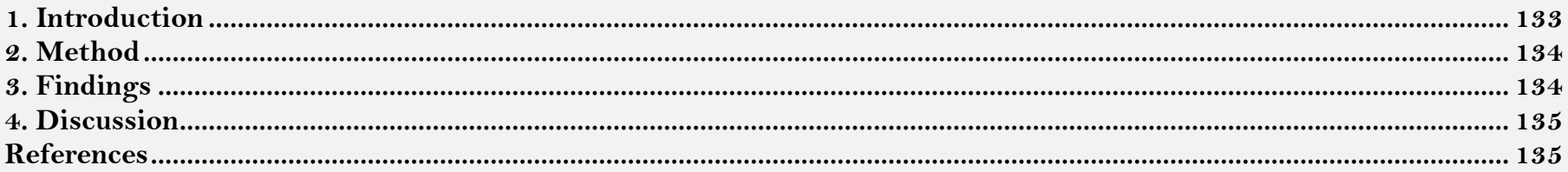




\section{Introduction}

The technological developments that have directed 21 st century skills have brought new content and dimension to narrative by integrating story narration, one of the earliest verbal narrative skills of mankind, with digital technology. Lambert (2010) took the lead in the creation of stories using digital media and began to call this process digital narrative. A lot of definitions are encountered when examining the literature about digital narrative. According to Armstrong (2003) digital narration is sharing of information transfer or storytelling through media. Digital storytelling is usually the creation of short films from personal narratives and reflection of these films on television, computer screens or projectors (Davis, 2002). Mellon (1999) describes digital storytelling as combining storytelling with multimedia software techniques. According to Dreon et al. (2011) digital narration is the creation of storytelling art supported by different means. It seems that these definitions actually cover far-reaching actions that the technology at that time makes possible. Today, it is possible to refer to a new structure that is created in computer environment rather than reflecting the digital narrative with the projector, including personal and historical events as well as educational contents. In the educational context, digital storytelling is a short story that students create by using visual and auditory multimedia facilities and environments (Meadows, 2003; Bull and Kajder, 2004; Robin, 2006). Robin and Pierson (2005) also described digital storytelling as the creation of meaningful stories that capture the imagination of students and teachers and praise their experiences. In addition, because digital narration can reach millions of readers via the Internet, the impact size is greater than other materials (Standley, 2003).

There are many types of digital stories in the literature. However, Robin (2006) collects digital narrative types under three main headings: Informative and instructive narratives, personal (reflective) narratives and historical narratives. On the other hand, Garrety (2008) distinguishes five sets of digital stories: Traditional narratives, didactic narratives, project-based narratives, social justice and cultural narratives, and finally narratives reflecting one's inner world. There are also a number of constitutive items in digital narration. Lambert (2010) identified seven items for the creation of effective digital stories: Point of view, striking question, emotional content, use of sound, music, economy and rhythm.

Another concept that 21 st century skills have brought forward is digital media literacy. Both literacy and digital media-oriented literacy concepts are indeed a reflection of the changing technological process. This reflection is more noticeable in the context of educational technologies. According to Karakoyun (2014) in particular, students need to learn how to use 21 st-century tools to effectively use multimedia content and digital content, starting from primary education. Students growing in the 21 st century society are individuals with high expectations demanding that schools with technology infrastructure, use of digital media in lessons, group work, game-centered learning and adaptation of learners to individuals (Kerr, 2005; Oblinger and Oblinger, 2005; Ohler, 2006; Moyle and Owen, 2009). Gils (2005) emphasizes that the use of digital story in education has many benefits. These benefits are described as different from traditional methods, personalizing learning, increasing student participation, making real life situations easier and cheaper, and making learning of subjects more interesting. It is also thought that the arrangement of the mother tongue education according to the abovementioned contents can be an important factor in the realization of the 21 st century learning. Because of the nature of mother tongue education, it gives opportunity to media use, group work and game centered activities. The development of reading, speaking, listening and writing activities in the digital environment starting from the primary school is expected to have a positive impact on both mother tongue education and how the digital world should be used. However, the number of the research in the field of digital story and digital media-oriented reading, especially in the context of language education falls short. Digital narration, however, is functional in that both prospective teachers are able to maintain the development of the 21 st century skills and it is an effective material tool. The creation of a techno pedagogical educational environment for language education, the use of digital stories in the development of digital literacy in 21 st century skills and the testing of educational reflections of these processes are leading priorities of the study.

There are many studies on digital narration. Yavuz (2015) investigated the effect of creating digital story on resistance behaviours and learning approaches of teacher candidates. Sadik (2008) and Razmi et al. (2014) studied the effect of preparing digital stories on language skills of learners while Yanpar et al. (2015) examined the effects of preparing digital stories on technological pedagogical field knowledge of teacher candidates, Çıralı (2014) investigated the effect of digital storytelling on students' visual memory capacity and writing skills, and Balaman (2016) studied the influence of digital storytelling on students' attitudes towards teaching techniques. Use of digital story in open learning systems is argued by Yüzer and Kılınç (2015) while digital story narration as a means of expression is discussed by Küngerü (2016) the changing nature of storytelling through technology during teaching process by Kocaman (2015) and digital narration in children as a technology-focused visual communication and a dynamic way of visual communication by Bedir (2017). In addition to these studies, there are also academic studies in which digital story is taken in different fields such as the use of digital story as a material designing tool (Yürük and Atici, 2016) and digital story use in foreign language education (Tatlı and Aksoy, 2016). In these studies, there was no study in which native language education and digital literacy were associated with digital story. In the context of the literature review above, the aim of this research is to determine the effects of web-based digital story writing on the perceptions of Turkish teacher candidates on digital media-oriented literacy self-efficacy. The main problem of the research for this purpose is the question "What is the effect of web-based digital story preparation in the course of Instructional Principles and Methods of Turkish teacher candidates on digital media-focused literacy self-efficacy perceptions?" The other subproblems underlying the main problem are listed as follows:

1) Is there a significant difference between pre-test and post-test scores of self-efficacy perceptions of Turkish teacher candidates who prepare a web-based digital story in collaborative learning approach?

2) Is there a significant difference between pre-test and post-test scores of self-efficacy perceptions of Turkish teacher candidates who prepare course activities based on collaborative learning approach? 


\section{Method}

The pre-test, post-test, test-control group and semi-experimental design were used in the study that examines the effect of web-based digital story preparation of the Turkish teacher candidates in the course of Instructional Principles and Methods on their digital media-oriented literacy self-efficacy perceptions. The experimental model is a research area under the control of the researcher where the data desired to be observed for discovering the causeand-effect relationships between variables are produced (Büyüköztürk, 2007; Karasar, 2016). Semi-experimental design is the most commonly used experimental design, especially in the field of education, where it is not possible to control all variables. In this model, groups are formed as experimental and control groups by unbiased assignment (Büyüköztürk, 2007; Balcı, 2016). Because the semi-experimental design was used in the research, universe and sample were not selected; instead, study groups were taken and the equality of groups was emphasized. In the control group, the Instructional Principles and Methods course was continued while, in the experimental group, web based digital story applications were realized. The Research Design of the research process is shown in Table 1 .

Table-1. Research Design

\begin{tabular}{l|l|l|l|l}
\hline Group & Matching & Pre-test & Process & Post-test \\
\hline $\begin{array}{l}\text { Experimental } \\
\text { Group }(G 1)\end{array}$ & $\begin{array}{l}\text { Academic } \\
\text { achievement } \\
\text { scores }\end{array}$ & $\begin{array}{l}\text { Digital Media- } \\
\text { Oriented Literacy } \\
\text { Self-efficacy Scale }\end{array}$ & $\begin{array}{l}\text { Creating a web based digital } \\
\text { story with collaborative } \\
\text { learning approach }\end{array}$ & $\begin{array}{l}\text { Digital Media- } \\
\text { Oriented Literacy Self- } \\
\text { efficacy Scale }\end{array}$ \\
\hline $\begin{array}{l}\text { Control Group } \\
\text { (G2) }\end{array}$ & $\begin{array}{l}\text { Academic } \\
\text { achievement } \\
\text { scores }\end{array}$ & $\begin{array}{l}\text { Digital Media- } \\
\text { Oriented Literacy } \\
\text { Self-efficacy Scale }\end{array}$ & $\begin{array}{l}\text { Course activities based on } \\
\text { collaborative learning approach }\end{array}$ & $\begin{array}{l}\text { Digital Media- } \\
\text { Oriented Literacy Self- } \\
\text { efficacy Scale }\end{array}$ \\
\hline
\end{tabular}

\subsection{Data Collection Tools}

The research data were collected with the "Digital Media-Oriented Literacy Self-efficacy Scale" developed by researchers. The alpha reliability of the scale is 0.94 , while the reliability of the factors are $0.911 ; 0.897 ; 0,857$ and 0,761 respectively.

\subsection{Participants}

60 of the 2nd grade students who attended in the Teaching Principles and Methods Course in Mersin University Education Faculty Turkish Education Department in the 2016-2017 academic year participated in this study.

\section{Findings}

Whether there is a significant difference between pre-test and post-test scores of self-efficacy perceptions of Turkish teacher candidates who prepare a web-based digital story in collaborative learning approach was examined. The t-test results for the related samples are shown in Table 2 to determine whether there is a significant difference between pre-test and post-test scores of the digital media-oriented literacy self-efficacy perceptions of the teacher candidates in the experimental group.

Table-2. Experiment Group Digital Media-Oriented Literacy Self-efficacy Scale Difference Between Pre-Test and Post-Test

\begin{tabular}{l|l|l|l|l|l|l}
\hline & $\mathbf{N}$ & $\mathbf{X}$ & $\mathbf{S}$ & $\mathbf{s d}$ & $\mathbf{t}$ & $\mathbf{p}$ \\
\hline Pre-Test & 37 & 74,21 & 11,05 & \multirow{2}{*}{36} & \multirow{2}{*}{$-2,53$} & \multirow{2}{*}{016} \\
\hline Post-Test & 37 & 80,81 & 10,46 & & \\
\hline
\end{tabular}

As seen in Table 2 , the arithmetic mean of the pre-test scores of the teacher candidates' digital media-oriented self-efficacy scale is $\mathrm{x}=74,21 ; \mathrm{S}=11.05$ while their arithmetic mean of the post-test scores is $\mathrm{x}=80,81, \mathrm{~S}=10,46$. Considering the arithmetic mean, it seems that there is an increase in favour of the post-test in the digital mediaoriented self-efficacy of the experimental group after the application. According to this result, it can be said that the digital media-oriented self-efficacy beliefs of teacher candidates are quite high. In addition, it can be indicated that there is a significant difference $\left(\mathrm{t}_{(36)}=-2,53 ; \mathrm{p}=0,016<0,05\right)$ between the pre-test scores and the post-test scores of the prospective teachers and this increase is in favour of the post-test.

Whether there is a significant difference between pre-test and post-test scores of self-efficacy perceptions of Turkish teacher candidates who prepare course activities based on collaborative learning approach was examined. The t-test results for the related samples are shown in Table 3 to determine whether there is a significant difference between pre-test and post-test scores of the digital media-oriented literacy self-efficacy perceptions of the teacher candidates in the control group.

Table-3. Control Group Digital Media-Oriented Literacy Self-efficacy Scale Difference Between Pre-Test and Post-Test

\begin{tabular}{l|l|l|l|l|l|l}
\hline & $\mathbf{N}$ & $\mathbf{X}$ & $\mathbf{S}$ & sd & t & p \\
\hline Pre-Test & 37 & 70,29 & 13,97 & 36 & \multirow{2}{*}{$-1,309$} & \multirow{2}{*}{199} \\
\hline Post-Test & 37 & 74,21 & 11,05 & & \\
\hline
\end{tabular}

As seen in Table 3, the arithmetic mean of the pre-test scores of the teacher candidates' digital media-oriented self-efficacy scale is $\mathrm{x}=70,29 ; \mathrm{S}=13,97$ while their arithmetic mean of the post-test scores is $\mathrm{x}=74,21 ; \mathrm{S}=11,05$. Regarding the arithmetic mean, it seems that there is an increase in favour of the post-test in the digital mediaoriented self-efficacy of the control group after the application. According to this result, it can be said that the digital media-oriented self-efficacy beliefs of teacher candidates are quite high; however, this difference is not statistically significant $\left(\mathrm{t}_{(36)}=-2,53 ; \mathrm{p}=0,016<0,05\right)$. 


\section{Discussion}

In this study which aims to investigate the effects of Web-based digital story preparation on Turkish teacher candidates' digital literacy self-efficacy perceptions, teacher candidates were made to create digital stories according to the curriculum of their field. Within this context, the teacher candidates in the experimental group prepared their weekly lessons using digital story applications, while the control group prepared lesson plans. Both groups were applied "Digital Media-Oriented Literacy Self-efficacy Scale" for pre-test and post-test. An increase was observed in Digital Media-Oriented Literacy Self-efficacy levels in both groups as a result of the applications at the end of the semester. However, a statistically significant difference was found only between pre-test and post-test scores of the self-efficacy perceptions of the Turkish teacher candidates who prepared a web-based digital story in the cooperative learning approach. There may be some inferences about the increase in both groups. Although digital story is not used in the control group, digital media-oriented literacy self-efficacy levels show an increase in the arithmetic average; however, there is no statistical difference. The reason for this may be the indirect use of digital media in the preparation of teacher candidates' weekly assignments. While preparing the weekly lesson plans, the teacher candidates made researches in order to reach the information they needed, organized the information they obtained, added the pictures according to the contents of the lesson plan and tried to form a meaningful whole. It is inevitable that teacher candidates are not affected by the digital media in these processes.

There are some studies about the effect of digital narrative on digital literacy in the field of literature. According to Dogan (2012) students think that digital storytelling develops technological skills and media literacy the most. Besides, Ohler (2006) stated that digital narrative is a powerful tool to teach media literacy. Jakes (2006) also took 21 st century skills in four categories: digital age literacy, creative thinking, effective communication, and high productivity, and stated that digital narrative helped them earn these skills. Michalski et al. (2005) found that digital storytelling improves the students' written and verbal communication skills and increases their level of software knowledge and technology use. In his work, Balaman (2016) found that digital literacy has evolved in a positive way, particularly in the context of questioning technology literacy and the process of visual communication, with visual literacy being effectively implemented. Daigle (2008) stated that digital narrative requires knowledge of technology, writing skills and creativity. In addition, the digital narrative approach provides active participation of students and have positive effects by improving effective communication skills (Robin, 2008; Coutinho, 2010; Gyabak and Godina, 2011) aiding students to use communication technologies effectively (Jakes and Brennan, 2005) enabling different literacy areas in early childhood to be used effectively with technology integration (Bratitsis et al., 2012; Graham et al., 2012; Hung et al., 2012) and increasing their level of interest in the story theme and the Teaching Technologies they use (Balaman, 2016).

In conclusion, preparing a web based digital story in collaborative learning approach has an effect on digital media-oriented literacy self-efficacy perceptions of Turkish teacher candidates. For this reason, digital storytelling can both be used as an original material for native language teaching of teacher candidates and have an effective function in the development of 21 st century skills of teacher candidates. This study was carried out by taking only the Teaching Principles and Methods course of teacher candidates. In other similar studies, digital storytelling approach can be utilized by taking into consideration the content of both field courses and culture courses. Researchers can study the effects of digital narrative in terms of various variables.

\section{References}

Armstrong, S., 2003. The power of storytelling in education. S. Armstrong (Ed.), Snapshots! educational insights from the Thornburg Center içinde. Lake Barrington, Illinois: The Thornburg Center. pp: $11-20$.

Balaman, F., 2016. The effect of digital narrative method on the attitudes of students towards teaching technologies. Pegem Journal of Education and Teaching, 6(2): 147-168. View at Google Scholar | View at Publisher

Balcı, A., 2016. Research methods, techniques and principles in social sciences. Ankara: Pegem A Publishing.

Bedir, E.S.D., 2017. Children's technology-focused visual communication and digital narrative as a way of dynamic visual communication. Istanbul University Communication Faculty Magazine, 2017(1): 25-38.

Bratitsis, T., T. Kotopoulos and K. Mandila, 2012. Kindergarten children's motivation and collaboration being triggered via computers while creating digital stories: A case study. International Journal of Knowledge and Learning, 8(3-4): 239-258. View at Google Scholar | View at Publisher

Bull, G. and S. Kajder, 2004. Digital storytelling in the language arts classroom. Learning \& Leading with Technology, 32(4): 46-49. View at Google Scholar

Büyüköztürk, Ş., 2007. Manual of data analysis for social sciences. Ankara: Pegem A Publishing.

Çıralı, H., 2014. The impact of digital storytelling on visual memory and writing skills. Unpublished Master Thesis. Hacettepe University Educational Sciences Institute, Ankara.

Coutinho, C., 2010. Storytelling as a strategy for integrating technologies into the curriculum: Anempirical study with post-graduate teachers. In D. Gibson \& B. Dodge (Eds.), Proceedings of Society for Information Technology \& Teacher Education International Conference 2010. Chesapeake, VA: AACE. pp: 3795-3802.

Daigle, B.A., 2008. Digital storytelling as a literacy-based intervention for a sixth grade student with Autism spectrum disorder: An exploratory case study. Baton Rouge, La: Yayınlanmamış Doktora Tezi, Louisiana State University.

Davis, J.E., 2002. Stories of change: Narrative and social movements. New York: State University of New York.

Dogan, B., 2012. Educational uses of digital storytelling in K-12: Research results of digital storytelling contest (DISTCO) 2012. P. Resta (Ed.), Proceedings of Society for Information Technology \& Teacher Education International Conference 2012. Chesapeake, VA: AACE. pp: 1353-1362.

Dreon, O., R.M. Kerper and J. Landis, 2011. Digital storytelling: A tool for teaching and learning in the YouTube generation. Middle School Journal, 42(5): 4-10. View at Google Scholar $\mid$ View at Publisher

Garrety, C., 2008. Digital storytelling: An emerging tool for student and teacher learning. Ames. Yayınlanmamış Doktora Tezi, IA: Iowa State University.

Gils, F., 2005. Potential applications of digital storytelling in education. 3. Twente Student Conferance on IT, 17-18 Şubat, University of Twente, Fakülty of Electrical Engineering, Mathematics and Computer Science, enschede.

Graham, C.R., J. Borup and N.B. Smith, 2012. Using TPACK as a framework to understand teacher candidates' technology integration decisions. Journal of Computer Assisted Learning, 28(6): 530-546. View at Google Scholar $\mid$ View at Publisher

Gyabak, K. and H. Godina, 2011. Digital storytelling in Bhutan: A qualitative examination of new media tools used to bridge the digital divide in a rural community school. Computers \& Education, 57(4): 2236-2243. View at Google Scholar | View at Publisher

Hung, C.M., G.J. Hwang and I. Huang, 2012. A project-based digital storytelling approach for improving students' learning motivation, problem-solving competence and learning achievement. Educational Technology \& Society, 15(4): 368-379. View at Google Scholar

Jakes, D., 2006. Standards-proof your digital storytelling efforts. Tech Learning. Retrieved from http://xrl.us/digitalstoryguidelines [Accessed August 28, 2017]. 
Jakes, D.S. and J. Brennan, 2005. Capturing stories, capturing lives: An introduction to digital storytelling. Retrieved from http://bookstoread.com/etp/earle.pdf [Accessed 28 August 2017].

Karakoyun, F., 2014. An examination of the views of prospective teachers and primary school students on digital narrative activities created in an online setting. Unpublished PhD Thesis. Anadolu University Educational Sciences Institute, Eskişehir.

Karasar, N., 2016. Scientific research method. Ankara: Nobel Publishing.

Kerr, N.Y., 2005. For the net generation - must exemplary teaching include technology? A case study at Champlain College. Boston College, USA: Yayınlanmamış Doktora Tezi.

Kocaman, K.A., 2015. The changing nature of storytelling in the teaching process: Digital storytelling. Teaching Technology Theory and Practice, 5(2): 89-106. View at Google Scholar

Küngerü, A., 2016. Digital storytelling as a means of expression. Abant Magazine for Cultural Research, 1(2): 33-45.

Lambert, J., 2010. Digital storytelling cookbook and traveling companion. Berkeley, CA: Digital Diner Press.

Meadows, D., 2003. Digital storytelling: Research-based practice in new media. Visual Communication, 2(2): 189-193. View at Google Scholar View at Publisher

Mellon, C.A., 1999. Digital storytelling: Effective learning through the internet. Education Technology, 39(2): 46-50. View at Google Scholar

Michalski, P., D. Hodges and S. Banister, 2005. Digital storytelling in the middle childhood special education classroom: A teacher's story of adaptations. Teaching Exceptional Children Plus, 1(4): 1-13. View at Google Scholar

Moyle, K. and S. Owen, 2009. Listening to students' voices: What are the views of learners' and early career educators' about learning with technologies in Australian education and training? Research findings. Canberra: DEEWR.

Oblinger, D.G. and J.L. Oblinger, 2005. Educating the net generation. Washington, D.C: Educause.

Ohler, J., 2006. The world of digital storytelling. Educational Leadership, 63(4): 44-47. View at Google Scholar

Razmi, M., S. Pourali and S. Ve Nozad, 2014. Digital storytelling in EFL classroom (Oral Presentation of the Story): A pathway to improve oral production. Procedia-Social and Behavioral Sciences, 98: 1541-1544. View at Google Scholar | View at Publisher

Robin, B., 2006. The educational uses of digital storytelling. C. Crawford vd. (Ed.), Proceedings of Society for Information Technology \& Teacher Education International Conference, 2006. Chesapeake, VA: AACE. pp: 709-716.

Robin, B. and M. Pierson, 2005. A multilevel approach to using digital storytelling in the classroom. C. Crawford vd. (Ed.), Proceedings of Society for Information Technology \& Teacher Education International Conference 2005. Chesapeake, VA: AACE. pp: 708-716.

Robin, B.R., 2008. Digital storytelling: A powerful technology tool for the 21 st century classroom. Theory into Practice, 47(3): 220-228. View at Google Scholar | View at Publisher

Sadik, A., 2008. Digital storytelling: A meaningful technology-integrated approach for engaged student learning. Educational Technology Research and Development, 56(4): 487-506. View at Google Scholar | View at Publisher

Standley, M., 2003. Digital storytelling: Using new technology and the power of stories to help our students learn-and teach. Cable in the Classroom. Retrieved from http://www.mediachalk.com/DigitalStorytellingAlaska.pdf $[$ Accessed 28.08.2017].

Tatlı, Z. and D.A. Aksoy, 2016. Use of digital story in foreign language speech training. Marmara university atatürk education faculty. Journal of Educational Sciences, 45: 137-152.

Yanpar, Y.T., H.E. Çocuk, K.G. Yavuz and V.L. PAN, 2015. The effect of digital story preparation on technological pedagogical content knowledge (tpck) self-confidence. Anthropologis, 22(2): 185-195. View at Google Scholar |View at Publisher

Yavuz, K.G., 2015. Influence of constructing digital story based on research based learning approach to resis tance behaviors and learning approaches of teacher candidates. Unpublished PhD Thesis. Mersin University Institute of Educational Sciences, Mersin.

Yürük, S.E. and B. Atici, 2016. The value of digital story-based educational materials is an influence on students' appreciation. Trakya University Education Faculty Magazine, 7(1): 56-74.

Yüzer, T.V. and H. Kılınç, 2015. To benefit from digital narration in open learning systems. Journal of Education and Training Researches, $4(1): 243-250$. 